
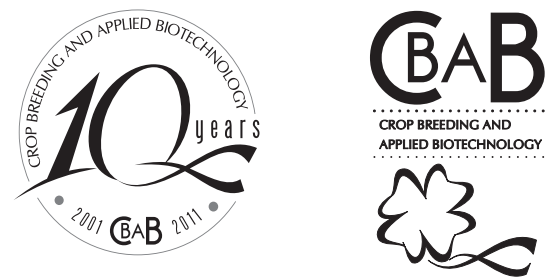

\title{
Genetic variability among cassava accessions based on SSR markers
}

\author{
Márcia de Nazaré Oliveira Ribeiro ${ }^{1}$, Samuel Pereira de Carvalho $^{1}$, João Bosco dos Santos ${ }^{1}$ and Rafaela Priscila Antonio ${ }^{1}$
}

Received 22 October 2010

Accepted 5 February 2011

\begin{abstract}
The aim of this study was to characterize and estimate the genetic similarity among 93 cassava accessions. The DNA amplification was performed with 14 microsatellite primers. The amplification products were separated by a polyacrylamide gel electrophoresis, showing a polymorphism formation, through which the accessions were discriminated against. The genetic similarity among accessions of cassava was estimated by the Dice coefficient. Cluster analysis was carried out using the UPGMA method. The polymorphic primers amplified a total of 26 alleles with 2-4 alleles per loci. The genetic similarity ranged from 0.16 to 0.96 . The average values for observed and expected heterozygosity were 0.18 and 0.46 , respectively. Twenty genetic similarity clusters were determined, demonstrating diversity among accessions, suggesting the possibility of heterotic hybrid generation.
\end{abstract}

Key words: Manihot esculenta; microsatellites; genetic characterization.

\section{INTRODUCTION}

Cassava (Manihot esculenta Crantz) is the staple food of nearly 700 million people worldwide. It is the only species of the genus Manihot grown commercially for the production of edible roots. It adapts to different climate and soil conditions and can be found from the Southern U.S. to northern Argentina. Generally, it is planted in marginal areas with low productivity (Fukuda and Iglesias 2006). The species has a large genetic diversity due to the ease of pollination, high heterozygosity and sudden dehiscence of the fruit, leading to a continuously infinite number of new genotypes. In Brazil, the wide genetic variability of cassava is kept in on-site collections and germplasm banks distributed throughout the country. This variability is represented mostly by native varieties or those naturally selected by farmers.
The conservation of cassava germplasm is essential in reducing the genetic erosion of species and genetic diversity available to help improve the culture. In cassava this erosion is mainly due to the expansion of agricultural frontiers, the advancement of urbanization, and the biotic and abiotic stresses and to a lesser extent, by the replacement of traditional varieties by improved varieties (Fukuda et al. 1996). The characterization of the species diversity is important for germplasm conservation. Estimating the degree of relatedness between accessions makes it possible to eliminate possible duplicates and more efficient use of them in breeding programs.

The DNA markers are useful in studies of evolution, domestication, ecology and phylogeny of plants and also for genetic mapping and cloning of genes. Therefore, allowing a short term evaluation of a large number of genotypes without environmental influence (Costa et al.

\footnotetext{
${ }^{1}$ Universidade Federal de Lavras, Campus Universitário, P.O. Box 3037, 37.200-000, Lavras, MG, Brazil. *E-mail: marcia_162@hotmail.com
} 
2003). The use of molecular markers in assessing the genetic diversity of cassava germplasm has been increasing in recent years, mainly due to the large amount of information concerning the genome of this species available (Colombo et al. 2000, Mühlen et al. 2000, Carvalho and Schaal 2001, Elias et al. 2001, Mba et al. 2001, Elias et al. 2004, Zaccarias et al. 2004). As cited by Faraldo et al. (2002), the molecular markers are very important techniques for the identification of accessions held by germplasm banks, whose purpose is to maintain genetic variability for subsequent use of the accessions. One type of molecular marker that is more informative in evaluating cassava germplasm is a microsatellite (Chavarriaga-Aguirre et al. 1998).

The aim of this study was to estimate the genetic variability among 93 accessions of cassava from the germplasm bank at the Federal University of Lavras for 14 microsatellite primers, enabling the identification of genetically divergent clones for polycrossing, aiming at the development of new clones.

\section{MATERIAL AND METHODS}

Part of the accessions held in the germplasm bank at UFLA was provided by Embrapa Cassava and Fruit Crops, Cruz das Almas, BA. These clones were used in field polycrossing, from where the new clones were obtained, which together with some commercial cultivars were evaluated in this study (Table 1).

Molecular analyses were performed at the Molecular Genetics Laboratory, Department of Biology (DBI) Federal University of Lavras. DNA samples of each accession were extracted according to the procedure used by Pereira et al. (2007). Subsequently the DNA was used for PCR amplification using 14 microsatellite primers (GA-5, GA12, GA-13, GA-16, GA-21, GA-57, GA-123, GA-126, GA127, GA-131, GA-134, GA-136, GA-140 and GA-161) preestablished by Chavarriaga-Aguirre et al. (1998).

Each amplification used $20 \mathrm{ng}$ DNA, $100 \mathrm{mM}$ of each dNTPs, $1 \mathrm{U}$ of taq DNA polymerase, buffer consisting of $50 \mathrm{mM}$ TRIS pH 8.3, $20 \mathrm{mM} \mathrm{KCl}, 2 \mathrm{mM} \mathrm{MgCl} 2,10 \mathrm{mg}$ BSA, $0.25 \%$ Ficoll $400,10 \mathrm{mM}$ of tartrazine and pure water. The final volume for each reaction was $12 \mathrm{iL}$. The amplification was performed in Eppendorf Mastercycler® Thermal Cyclers, which was used in the following program: one step at $95{ }^{\circ} \mathrm{C}$ for two minutes for initial denaturation, followed by 32 cycles at $94{ }^{\circ} \mathrm{C}$ for 20 seconds each for DNA denaturation, 40 seconds for annealing primer at 47 ${ }^{\circ} \mathrm{C}, 40$ seconds for extension at $72{ }^{\circ} \mathrm{C}$, followed by a final extension at $72{ }^{\circ} \mathrm{C}$ for four minutes.
After amplification, the reaction products were separated by electrophoresis in polyacrylamide gel (19:1 Acrylamide: Bis) $6 \%$, non denaturant, in TBE buffer at $130 \mathrm{~V}$ for two hours. For revelation of the gels a staining method was used with silver nitrate. After electrophoresis, the plates were separated and the gel was immersed in 1 liter of a fixative solution ( $10 \%$ ethanol, $0.5 \%$ acetic acid) and kept under slow agitation for 15 minutes. Then, the gel was submerged in 1 liter of a silver nitrate solution (AgNO3) $(0.2 \%)$ under slow agitation for 10 minutes. The gel was then washed with water and slowly stirred in a solution of revelation ( $3 \% \mathrm{NaOH}, 0.5 \%$ formaldehyde) until complete visualization. The bands were then photographed using a Sony Cyber-shot DSC-W30 for later analysis.

The identification of DNA fragments amplified by microsatellite markers was done by performing a visual analysis. Each microsatellite band was evaluated for the 93 accesses, identifying the presence of a band by 1 and for an absence by 0 . From the matrix 0 and 1 genetic similarity $\left(\mathrm{sg}_{\mathrm{ij}}\right)$ was estimated between all pairs of genotypes using the Dice coefficient (Dice 1945): $\mathrm{sg}_{\mathrm{ij}}=2 \mathrm{a} /(2 \mathrm{a}+\mathrm{b}+\mathrm{c})$, which a corresponds to the presence of a band on the individual $i$ and $j$; $\mathbf{b}$ represents the presence of the band in $i$ and absence in $j$; and $\mathbf{c}$ represents the absence of the band in $i$ and presence in $j$. Analyses of similarity were performed using the program NTSYS version 2.1 (Rohlf 2000). Based on the coefficient similarity, the genotypes were clustered by UPGMA and represented in a dendrogram. The genetic difference among accessions was identified in the dendrogram given the estimate of the maximum significant similarity (sgm). The sgm was estimated by the t-test obtained by the expression: $\mathrm{sgm}=1-\left(\mathrm{t} \bar{S}_{\mathrm{sg}}\right)$, where $\mathrm{t}$ is the tabulated value of $\mathrm{t}$ with $\mathrm{n}-2$ degrees of freedom and is $\bar{S}_{\mathrm{sg}}$ the average error of $\mathrm{sg}_{\mathrm{ij}}$ (Hagiwara et al. 2001).

The genetic diversity parameter: number of alleles per locus and heterozygosity (observed and expected) were estimated using the software Popgene version 1.31 (Yeh et al. 1999).

\section{RESULTS AND DISCUSSION}

A total of 26 alleles were amplified with 14 SSR loci analyzed in 93 accessions. Of the 14 primers, 12 generated polymorphic (GA-5, GA-12, GA-16, GA-21, GA-57, GA123, GA-127, GA-131, GA-134, GA-136, GA-140 and GA161). The number of alleles observed per locus ranged 
Table 1. Accessions of cassava (Manihot esculenta Crantz) used in this study and their origins

\begin{tabular}{|c|c|c|c|c|c|c|c|c|}
\hline Code & Origin & Accession & Code & Origin & Accession & Code & Origin & Accession \\
\hline 1 & Lavras/MG & BAIANA & 32 & Lavras/MG & UFLA 5 & 63 & Lavras/MG & UFLA 31 \\
\hline 2 & Lavras/MG & UFLA 7 & 33 & Campinas/SP & IAC 13 & 64 & Carrancas/MG & AMARELINHA \\
\hline 3 & Lavras/MG & CASCA ROXA & 34 & Lavras/MG & SEIS MESES & 65 & Lavras/MG & UFLA 49 \\
\hline 4 & Lavras/MG & UFLA H & 35 & Lavras/MG & UFLA 76 & 66 & Lavras/MG & UFLA 12 \\
\hline 5 & Lavras/MG & UFLA 30 & 36 & Lavras/MG & LT 2 & 67 & Lavras/MG & UFLA 58 \\
\hline 6 & Lavras/MG & UFLA 4 & 37 & Campinas/SP & MOCOTÓ & 68 & Lavras/MG & UFLA 71 \\
\hline 7 & Lavras/MG & UFLA 48 & 38 & Lavras/MG & UFLA 57 & 69 & Lavras/MG & UFLA 36 \\
\hline 8 & Lavras/MG & UFLA 42 & 39 & Lavras/MG & UFLA 11 & 70 & Lavras/MG & UFLA 53 \\
\hline 9 & Lavras/MG & UFLA 90 & 40 & Lavras/MG & UFLA 65 & 71 & Patos de Minas/MG & MANABOW \\
\hline 10 & Lavras/MG & UFLA 2 & 41 & Lavras/MG & UFLA 18 & 72 & Lavras/MG & UFLA 28 \\
\hline 11 & Campinas/SP & IAC 57660 & 42 & Lavras/MG & UFLA 61 & 73 & Lavras/MG & UFLA 77 \\
\hline 12 & Lavras/MG & UFLA 63 & 43 & Campinas/SP & IAC 12 & 74 & Lavras/MG & UFLA 73 \\
\hline 13 & Lavras/MG & UFLA 33 & 44 & Lavras/MG & UFLA 23 & 75 & Lavras/MG & UFLA 10 \\
\hline 14 & Lavras/MG & UFLA 59 & 45 & Lavras/MG & UFLA 8 & 76 & Lavras/MG & UFLA 46 \\
\hline 15 & Lavras/MG & UFLA G & 46 & Lavras/MG & JB & 77 & Lavras/MG & UFLA 60 \\
\hline 16 & Lavras/MG & UFLA 25 & 47 & Lavras/MG & UFLA 64 & 78 & Lavras/MG & UFLA 26 \\
\hline 17 & Lavras/MG & LT 4 & 48 & Lavras/MG & UFLA 13 & 79 & Lavras/MG & UFLA 32 \\
\hline 18 & Lavras/MG & UFLA 9 & 49 & Lavras/MG & UFLA 51 & 80 & Lavras/MG & UFLA 20 \\
\hline 19 & Lavras/MG & UFLA 19 & 50 & Lavras/MG & UFLA 60 & 81 & Lavras/MG & UFLA 72 \\
\hline 20 & Lavras/MG & UFLA 41 & 51 & Campinas/SP & IAC 14 & 82 & Lavras/MG & UFLA 29 \\
\hline 21 & Lavras/MG & DESCONHECIDO 3 & 52 & Lavras/MG & UFLA 66 & 83 & Campinas/SP & OURO DO VALE \\
\hline 22 & Campinas/SP & FIBRA & 53 & Lavras/MG & UFLA 21 & 84 & Lavras/MG & UFLA 62 \\
\hline 23 & Lavras/MG & UFLA E & 54 & Carrancas/MG & PINHEIRA & 85 & Lavras/MG & UFLA 67 \\
\hline 24 & Lavras/MG & UFLA 47 & 55 & Lavras/MG & UFLA 75 & 86 & Lavras/MG & UFLA 22 \\
\hline 25 & Lavras/MG & LT 1 & 56 & Lavras/MG & UFLA 17 & 87 & Lavras/MG & UFLA 38 \\
\hline 26 & Lavras/MG & LT 3 & 57 & Lavras/MG & UFLA 27 & 88 & Lavras/MG & BAIANA II \\
\hline 27 & Lavras/MG & UFLA 16 & 58 & Lavras/MG & UFLA 24 & 89 & IAPAR/PR & PIONEIRA \\
\hline 28 & Lavras/MG & UFLA 39 & 59 & Lavras/MG & BAIANINHA & 90 & Campinas/SP & IAC 57670 \\
\hline 29 & Lavras/MG & UFLA 52 & 60 & Lavras/MG & UFLA 15 & 91 & Campinas/SP & MOCOTÓ \\
\hline 30 & Lavras/MG & UFLA 40 & 61 & Lavras/MG & UFLA J & 92 & Lavras/MG & PÃO DA CHINA \\
\hline 31 & Campinas/SP & IAC 15 & 62 & Lavras/MG & UFLA 45 & 93 & Confresa/MT & NI \\
\hline
\end{tabular}

from 2-4 with an average of 2.2 alleles per locus and the most informative primer GA-131 was amplified by having a larger number of alleles (Table 2).

In this study, the findings resemble those of Roa et al. (2000). These authors, working with the amplification of DNA from cassava by means of microsatellite markers, found a higher polymorphism with the same primer GA131. Mühlen et al. (2000) studied the genetic variability of cassava landraces assessed by microsatellite markers; obtained $97.96 \%$ of polymorphic primers, with the total number 2-8 alleles per locus and an average of 4.5 alleles per loci.

Assessment of diversity using molecular markers has confirmed the wide genetic variability of cassava, but some comparisons with wild species indicate that they may contain as much or more variability than those cultivated.
Table 2. Number of alleles per locus (A), observed heterozygosity $\left(H_{o}\right)$ and expected heterozygosity $\left(H_{e}\right)$

\begin{tabular}{lccc}
\hline Primer & $\mathbf{A}$ & $\mathbf{H}_{\mathbf{o}}$ & $\mathbf{H}_{\mathbf{e}}$ \\
\hline GA-5 & 2 & 0.52 & 0.49 \\
GA-12 & 2 & 0.00 & 0.45 \\
GA-16 & 2 & 0.20 & 0.34 \\
GA-21 & 2 & 0.00 & 0.49 \\
GA-57 & 2 & 0.00 & 0.42 \\
GA-123 & 2 & 0.00 & 0.48 \\
GA-127 & 2 & 0.00 & 0.49 \\
GA-131 & 4 & 0.56 & 0.69 \\
GA-134 & 2 & 0.00 & 0.49 \\
GA-136 & 2 & 0.00 & 0.42 \\
GA-140 & 2 & 0.31 & 0.45 \\
GA-161 & 2 & 0.56 & 0.49 \\
\hline Average & $\mathbf{2 . 2}$ & $\mathbf{0 . 1 8}$ & $\mathbf{0 . 4 6}$ \\
\hline
\end{tabular}


Wanyera et al. (1992) using polymorphism of 13 isozyme loci, analyzed the genetic variability of 20 plants of $M$. glaziovii, 20 cassava clones and 49 clones of cassava tree, collected in Nigeria, and found higher diversity among cassava trees, followed by M. glaziovii and less variability among the cassava clones.

Heterozygosity can be considered a measure of genetic variability. This measure refers to how much of that variation exists in the population and how that variation is distributed across the alleles of an analyzed locus. Low heterozygosity means little genetic variability. It is considered a polymorphic locus when the most common allele frequency is less than 0.95 (Menezes et al. 2006). The heterozygosity of a marker is the probability of an individual being heterozygous at a marker locus, and this depends on the number of alleles and their frequency in the population.

The observed heterozygosity $\left(H_{o}\right)$ is the proportion of heterozygous individuals in population samples, expected heterozygosity $\left(H_{e}\right)$ is the probability of an individual being heterozygous in any locus. In this study, the highest heterozygosity values observed and expected (Table 3 ) were achieved with primer GA-131 $\left(H_{o}=0.56\right.$ and $H_{e}=0.69$ ). The observed heterozygosity showed low values in relation at expected heterozygosity values in most of the loci, indicating homozygous in excess. $58 \%$ of the polymorphic primers were homozygous and this suggests that sexual reproduction from the 93 clones must have had a high rate of self-pollination. Another possibility is that the clones originated from small populations or high levels of inbreeding.

The accessions showed values among 0.00 and 0.56 to observed heterozygosity and values among 0.34 and 0.69 to expected heterozygosity. The average achieved for these indexes were $H_{o}=0.18$ and $H_{e}=0.46$. Roa et al. (2000) found for 10 microsatellite loci, levels of expected heterozygosity $H_{e}=0.43$ (38 accessions of Manihot esculenta), $H_{e}=0.31$ (26 accessions of Manihot carthaginensis), $H_{e}=0.54$ (16 accessions of Manihot esculenta ssp. flabellifolia) and $H_{e}=0.32$ (Manihot esculenta ssp. peruviana). The index of heterozygosity observed were $H_{o}=0.63 ; H_{o}=0.12 ; H_{o}=0.44$ and $H_{o}=0.31$ respectively. Lefèvre and Charrier (1993) found rates of heterozygosity for 17 polymorphic isozyme loci of 0.225 in 365 accessions of cassava and 0.252 in 109 accessions of M. glaziovii.

The dendrogram (Figure 1) in the cluster analysis indicates genetic variability among analyzed accessions and it was observed that the amplitude in the similarity coefficient of Dice ranged from 0.50 to 1.00. There was also the presence of four pairs of duplicates [(UFLA 65 (40)/UFLA 10 (75); UFLA 75 (55)/UFLA 17 (56); UFLA 61 (42)/UFLA 8 (45) and UFLA 24 (58)/BAIANINHA (59)]. The cassava germplasm is made up of varieties and natural hybrids found in places of origin, collections and in the production areas in several countries.

These genotypes are often given confusing names, sometimes assigning the same name to different access or different names to the same access, which complicates the correct identification of the material and may cause the presence of duplicates in germplasm banks. Thus, based on this same rationale, it is noted in Table 1, different accessions of the same name (accessions 37 and 91 MOCOTÓ and accessions 50 and 77 - UFLA 60). Those through the dendrogram are in different groups.

Coefficients of similarity between the 93 cassava accessions ranged from 0.16 to 0.96 . The lowest genetic similarity (0.16) was observed among accessions UFLA 60 and UFLA 76, while the highest genetic similarity was observed between UFLA 9 and DESCONHECIDO 3; UFLA 25 and LT 3 ; IAC 12 and UFLA 73 all with a 0.96 similarity. After estimating the genetic similarities and considering the similarity of $69 \%$ among clones, we observed the formation of 20 groups.

Coefficients of similarity between the 93 cassava accessions ranged from 0.16 to 0.96 . The lowest genetic similarity (0.16) was observed among accessions UFLA 60 and UFLA 76, while the highest genetic similarity was observed between UFLA 9 and DESCONHECIDO 3; UFLA 25 and LT 3 ; IAC 12 and UFLA 73 all with 0.96 similarity. After estimating the genetic similarities and considering the similarity of $69 \%$ among clones, we observed the formation of 20 groups.

The groups formed were: Group I (BAIANA and UFLA 30), Group II (UFLA 63 and UFLA 19), Group III (UFLA 59, IAC 15, UFLA 29, UFLA 60 and UFLA 67), Group IV (UFLA 7, UFLA 16, UFLA 21, UFLA 71, CASCA ROXA, UFLA 48, UFLA 65, UFLA 10, AMARELINHA, IAC 14 and UFLA 49), Group V (UFLA G, LT 2, UFLA 72, UFLA 77, UFLA 22, MOCOTÓ, UFLA 31 and UFLA 20), Group VI (UFLA 32 and PIONEIRA), Group VII (UFLA 4, UFLA 45, PINHEIRA, UFLA 58, UFLA 18, UFLA 27, UFLA 36 e UFLA 13), Group VIII (LT4, UFLA 9, DESCONHECIDO 3, UFLA 12, UFLA 53, MANABOW and UFLA 64), Group IX (UFLA 51 and UFLA 62), Group X(UFLA 57), Group XI (UFLA 42 and JB), Group XII (FIBRA, UFLA E and UFLA 60), Group 


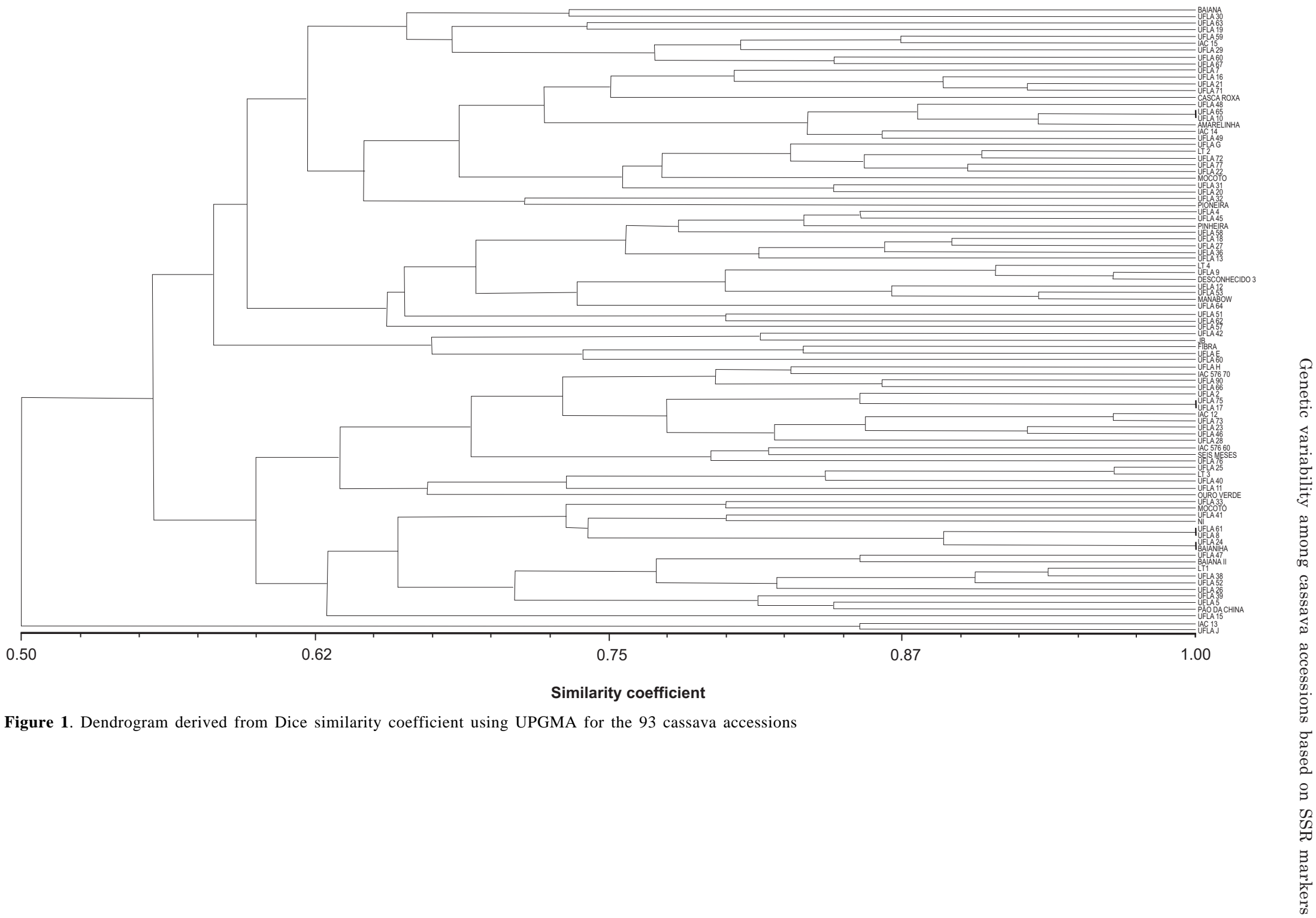


MNO Ribeiro et al.

XIII (UFLA H, IAC 576 70, UFLA 90, UFLA 66, UFLA 2, UFLA 75, UFLA 17, IAC 12, UFLA 73, UFLA 23, UFLA 46 and UFLA 28), Group XIV (IAC 576 60, SEIS MESES and UFLA 76), Group XV (UFLA 25, LT 3, UFLA 40 and UFLA 11), Group XVI (OURO DO VALE), Group XVII (UFLA33, MOCOTÓ, UFLA 41, NI, UFLA 61, UFLA 8, UFLA 24 and BAIANINHA), Group XVIII (UFLA 47, BAIANA II, LT 1, UFLA 38, UFLA 52, UFLA 26, UFLA 39, UFLA 5 and PÃO DA CHINA), Group XIX (UFLA 15), Group XX (IAC 13 and UFLA J).

Group XIII, composed of 12 accessions or $12.90 \%$ of the total was the largest. Followed by group IV with 11 $(11.83 \%)$, group XVIII with $9(9.68 \%)$; groups V, VII and XVII with eight accessions each (8.60\%), group VIII 7 $(7.53 \%)$, group III with five accessions $(5.38 \%)$, group XV $4(4.3 \%)$, groups XII and XIV with three $(3.22 \%)$, groups I, II, VI, IX, XI and XX with 2 each (2.15\%) and groups X, XVI, XIX with only one access (1.08\%). It was observed that the clustering method was effective in discriminating accesses as far as diversity, considering the large number of groups and the relatively low values of similarity between various approaches. However, there are very high values of $\mathrm{sg}_{\mathrm{ij}}$ between some clones as seen at 0.96 , which may mean access duplication. It is necessary to note the small number of bands and mainly the loci used. As similarity is an estimate of relatedness between the clones, based on a sample of the cassava genome, it was noticed that the sample was deficient. Consequently, the estimates may not be a true indicator of kinship. Therefore, more markers and morpho-agronomic characterization of clones should be considered for better definition of kinship, especially in the identification of duplicates to be eliminated from the germplasm.

The genotypes that showed high similarity (0.96) are UFLA 9/DESCONHECIDO 3, UFLA 25/LT 3 and IAC 12/UFLA 73. OURO DO VALE cultivar and new clones UFLA 57 and UFLA 15 are not grouped with any other material. The new clones UFLA 60 and UFLA 76 showed $16 \%$ similarity with these being the most divergent.

\section{CONCLUSIONS}

1. It was possible to demonstrate the variability among accessions of the cassava germoplasm cluster in twenty groups;

2. The microsatellite markers also identify possible duplicates in germplasm collections;

3. In this study, certain sequences of the primers were more suitable for the amplification of alleles.

\title{
Variabilidade genética entre acessos de mandioca com base em marcadores SSR
}

\begin{abstract}
RESUMO - Objetivou-se caracterizar e estimar a similaridade genética entre 93 acessos de mandioca. A amplificação do DNA foi realizada com 14 primers microssatélites. Os produtos de amplificação foram separados por eletroforese em gel de poliacrilamida, evidenciando-se a formação de bandas polimórficas, por meio das quais os acessos foram discriminados. A similaridade genética entre os acessos de mandioca foi estimada por meio do coeficiente de Dice. A análise de agrupamento foi feita com o método UPGMA. 26 alelos foram amplificados com 2 a 4 alelos por loco. O coeficiente de similaridade genética variou de 0,16 a 0,96. Os valores médios para heterozigosidade observada e esperada foram 0,18 e 0,46, respectivamente. 20 agrupamentos de similaridade genética foram detectados, demonstrando a existência de diversidade entre os acessos, sugerindo a possibilidade de geração de híbridos heteróticos.
\end{abstract}

Palavras-chave: Manihot esculenta, microssatélites, caracterização genética.

\section{REFERENCES}

Carvalho LJCB and Schaal BA (2001) Assessing genetic diversity in the cassava (Manihot esculenta Crantz) germplasm collection in Brazil using PCR-based markers. Euphytica 120: 133-142.
Chavarriaga-Aguirre P, Maya MM, Bonierbale MW, Kresovich S, Fregene MA, Tohme J and Kochert G (1998) Microsatellites in cassava (Manihot esculenta Crantz.): discovery, inheritance and variability. Theoretical and Applied Genetics 97: 493501.

Crop Breeding and Applied Biotechnology 11: 263-269, 2011 
Colombo C, Second G and Charrier A (2000) Diversity within american cassava germoplasm based on RAPD markers. Genetics and Molecular Biology 23: 189-199.

Costa MR, Cardoso ER and Ohaze MMM (2003) Similaridade genética de cultivares de mandioca (Manihot esculenta) por meio de marcadores RAPD. Ciência e Agrotecnologia 27: $158-164$.

Dice LR (1945) Measures of the amount of ecologic association between species. Ecology 26: 297-302.

Elias M, Mckey D, Panaud O, Anstett MC and Robert T (2001) Traditional management of cassava morphological and genetic diversity by the Makushi Amerindians (Guyana, South America): perspectives for on-farm conservation of crop genetic resources. Euphytica 120: 143-157.

Elias M, Mühlen GS, Mckey D, Roa AC and Tohme J (2004) Genetic diversity of traditional south american landraces of cassava (Manihot esculenta Crantz): an analysis using microsatellites. Economic Botany 58: 242-256.

Faraldo MIF, Silva RM, Ando A and Veasey EA (2002) Marcadores moleculares em mandioca. In Cereda MP (ed.) Agricultura: tuberosas amiláceas Latino Americanas. Fundação Cargill, São Paulo, p. 101-117.

Fukuda WMG, Costa IRS, Vilarinhos AD and Oliveira RP (1996) Banco de germoplasma de mandioca: manejo, conservação e caracterização. EMBRAPA, Cruz das Almas, 103p.

Fukuda WMG and Iglesias C (2006) Recursos genéticos. In Souza LS, Farias ARN, Mattos PLP and Fukuda WMG (eds.) Aspectos socioeconômicos e agronômicos da mandioca. EMBRAPA, Cruz das Almas, p. 301-323.

Hagiwara WE, Santos JB and Carmo SLM (2001) Use of RAPD to aid selection in common bean backcross breeding programs. Crop Breeding and Applied Biotechnology 1: 335-362.

Lefèvre F and Charrier A (1993) Isozyme diversity within African Manihot germoplasm. Euphytica 66: 73-80.
Mba REC, Stephenson P, Edwards K, Melzer S, Nkumbira J, Gullberg U, Apel K, Gale M, Tohme J and Fregene M (2001) Simple sequence repeat (SSR) markers survey of the cassava (Manihot esculenta Crantz) genome: towards an SSR-based molecular genetic map of cassava. Theoretical and Applied Genetics 102: 21-31.

Menezes MPC, Martinez AM, Ribeiro MN, Pimenta-Filho EC and Delgado JV (2006) Caracterização genética de raças caprinas nativas brasileiras utilizando-se 27 marcadores microssatélites. Revista Brasileira de Zootecnia 35: 1336-1341.

Mühlen GS, Martins PS and Ando A (2000) Variabilidade genética de etnovariedades de mandioca avaliada por marcadores moleculares de DNA. Scientia Agricola 57: 319-328.

Pereira HS, Santos JB, Abreu AFB and Couto KR (2007) Informações fenotípicas e marcadores microssatélites de QTL na escolha de populações segregantes de feijoeiro. Pesquisa Agropecuária Brasileira 42: 707-713.

Roa AC, Chavarriaga-Aguirre P, Duque MC, Maya MM, Bonierbale MW, Iglesias C and Tohme J (2000) Cross-species amplification of cassava (Manihot esculenta) (Euphorbiaceae) microsatellites: allelic polymorphism and degree of relationship. American Journal of Botany 87: 1647-1655.

Rohlf FJ (2000) NTSYS-pc: numerical taxonomy and multivariate analysis system, version 2.1. Exeter Software, Nova York.

Wanyera NMW, Hahn SK and Aken'ova ME (1992) Introgression of ceara rubber (Manihot glaziovii Muell-Arg) into cassava ( $M$. esculenta Crantz): a morphological and electrophoretic evidence. In Akoroda MO (ed.) Proceedings of root crops for food security in Africa. Africa Branch, Ibadan, p. 125-130.

Yeh FC, Boyle T, Ye Z and Xiyan JM (1999) Popgene version 1.31: microsoft window based freeware for population genetic analysis. University of Alberta and Center for international Forestry Research, Alberta.

Zaccarias AM, Botha AM, Labuschagne MT and Benesi IRM (2004) Characterization and genetic distance analysis of cassava (Manihot esculenta Crantz) germoplasm from Mozambique using RAPD fingerprinting. Euphytica 138: 49-53. 